\title{
Parenthetical Statements and Narrative Voices in Elsa Morante's Fiction*
}

Parenthetical statements are one of the trademarks of Elsa Morante's narrative techniques. However, if we examine the bibliographies that have appeared in the last decade, including the one compiled in the two volumes of the author's complete works, Opere (edited by Carlo Cecchi and Cesare Garboli), we notice that to date critics have ignored almost entirely the function of parentheses in Morante's fiction. This is surprising because the innumerable intervening statements are of a great variety and although they are usually brief and do not appear as actual digressive micronarratives, ${ }^{1}$ they are all clearly instrumental in underlining some information needed to construct a particular truth about specific characters or events, or even about the narrator. In short, Morante's parenthetical statements are much more than a stylistic technique, they are in fact an essential feature of her narrative discourse. ${ }^{2}$

Since the author's death, in 1985, we are finally seeing some new engaging close readings of her texts ${ }^{3}$ which also take into consideration familiar aspects of her style and language. For example, more recently, in the 1994 proceedings, "Vent'anni dopo La Storia. Omaggio a Morante," we find an excellent article by Pier Vincenzo Mengaldo, "Spunti per un'analisi linguistica dei romanzi di Elsa Morante," which focuses on some of the author's recurring linguistic features. Unfortunately, this insightful analysis deals exclusively with lexical issues (with, as he puts it, "materia lessicale" and "aggettivazione"), and only once Mengaldo mentions, indirectly, I must add, authorial assertions "i frequenti incisi per lo piú parentetici" (19).

I would think that, even for the obvious reason that parenthetical statements slow down our reading, as they force us to focus on certain words, expressions, statements, descriptions, events, or characters, one would be tempted to examine Morante's persistent use of authorial intrusions and see if it is a carefully cultivated strategy that discloses much more than a personal stylistic trait. I should clarify that here I am speaking exclusively of statements that appear between actual parentheses. A complete explanation of the overwhelming number of parenthetical assertions that appear between other forms of punctuation (especially commas) and in a variety of subordinate clauses, may indeed prove to be much too difficult, if not unrealistic (even with the help of an 
electronic text, as I have been conducting part of my research in the last few years). ${ }^{4}$

In Morante's novels the reader will notice quite easily that inside and outside the parentheses, in addition to the voice of the narrator (omniscient or otherwise) there is another distinct voice that narratologists usually identify as that of the implied author. These parentheses compel us to shift our attention from the narrator's storytelling to the presence of an even more authoritative voice that here I often refer to as the author's phantasm. ${ }^{5}$ And it is also through the juxtaposition of these voices that Morante fuses in a most unusual and brilliant fashion, fiction and facts, dreams and reality.

As a minimal illustration of this phenomenon here I must limit the examples to a few parenthetical statements from Menzogna e sortilegio, L'isola di Arturo and Aracoeli. Naturally, a more extensive and also more representative catalogue of samples from Morante's work would reinforce my argument demonstrating how the author has exploited, consistently, this stylistic device, both as a narrative strategy and as a psychological tool. In the space allowed and for the purpose of this paper it is sufficient to see how, beginning with her first major novel, Morante narrates constantly on different levels, and speaks frequently to the readers through a distinct voice which is clearly not always the one of the narrator. The examples that follow come from the introductory pages of Menzogna e sortilegio, where we first meet the I-narrator Elisa. From the opening chapter we notice that the parentheses vary from your typical, or if we wish classical interjection:

E la mia madre adottiva, pur non risparmiandomi talvolta le sue beffe (bonarie quasi sempre, ma in qualche occasione crude e brutali), tu tavia rispettò le mie consuetudini e non permise a nessuno di turbarle. (12)

Difatti, pur essendo per inclinazione e gusto suoi propri (non per nequizia della società o del destino), un'avventuriera dissoluta, ella si serbava tuttavia costante e devota nei suoi veri sentimenti. (15)

To authorial interventions:

Preferendo la sua presenza immaginaria (trasfigurata e domata dalla mia immaginazione secondo i miei desideri), alla sua presenza carnale. (15)

Solo mio compagno, dentro la stanza, è Alvaro, il quale è una creatura vivente, sí, ma non umana (altro di costui non voglio dirvi, per ora, né che cosa, né chi sia, riserbandovi la spiegazione del mistero, come nei romanzi polizieschi, alla fine del volume). (17)

In realtà, la mia vita (intendendo con la parola vita quelle prove, incontri ed eventi che compongono l'esperienza d'ognuno), la mia vita s'arresta al giorno che mi vide, bambina di dieci anni, entrar qui per la prima volta. (17) 
While others point clearly to autobiographical allusions:

Dapprima (ero appena una ragazzetta ancora), il mio non parve che un gioco, o un dilettoso esercizio. Richiusi i miei libri, io mi compiacevo di architettare, nella fantasia, vicende e storie di mia propria fattura, modellate, s'intende, sulle mie favole predilette. Or sebbene le trame da me immaginate variassero secondo i miei umori quotidiani, i protagonisti di esse, invece, eran sempre simili l'uno all'altro (se non proprio uguali), e quasi congiunti da una stretta parentela. (22)

In tal modo, il mio interesse per il fantastico esercizio raddoppiò, e la mia stramba epopea (la quale come certi romanzi pubblicati a dispense, non giungeva mai a conclusione), la mia stramba epopea, dico, m'avvinse al punto che la sera, addormentandomi, io smaniavo di giunger presto alla mattina, per riprendere il filo dell'avventura interrotta. (23)

In these and other obvious intrusions which range from purely descriptive addenda to careful metanarrative suggestions, we find the implied author making personal comments (including about her narcissism), explaining her metamorphosis, describing characters, places and events with additional details, interpreting important comments, or speaking directly to the readers. And, just as important, many of the parenthetical affirmations are instrumental in instilling an element of aesthetic and critical distance which helps readers and narrators to step back, briefly, from the story and thus preventing them from getting completely involved in the world/reality of the characters and events under scrutiny. This is the same type of distance that the author also employs for unveiling the hidden-selves of her narrators.

As brilliantly demonstrated by Marco Bardini and Manuela Scarano in the volume Per Elisa, psychoanalytical interpretations are essential for a deeper understanding of Morante's main characters and of her work in general. For practical reasons of space here I do not discuss the Oedipal complex that we find in practically every work of Morante, nor any other Freudian, Laingian or Lacanian interpretations which can be applied to the author's fiction and especially to her manifestations of "nevrosi narcisistica" (to quote Cesare Garboli), ${ }^{6}$ or "masochismo nichilista" (see Pupino 1968). In a chapter of my work in progress I discuss how "Hamlet"and "Oedipus" are two key literary and psychological figures frequently alluded to in our author's poetry, fiction and essays. Without having to recall the numerous instances, here I will just mention that in Morante's opus we recognize familiar voices that allude repeatedly to specific traumatic and conditioning factors, from childhood and adolescence, which may be at the foundation of a life-long unhappy drama that we see portrayed in both her male and female I-narrators (and which are at the end, in Aracoeli, all perfectly incorporated in Manuele).

For Elsa Morante narrating was certainly a passion and an art, but perhaps it was also a form of exhibitionism and, more importantly, a much needed (self)therapeutical experience. Her possible worlds are in many ways both a 
public and a private performance through which the second-self of the implied author, of the narrator, of some central characters, and of the real author meet in a variety of confrontational I-Other, love-hate, or even sado-masochistic relationships. In the act of writing the author reflects part of herself, while at the same time she is able to distance herself from her narrators and main characters. In short, she uses her fiction not so much as a mirror of her "social-self" (which was minimal indeed, especially from the Sixties on), ${ }^{7}$ but as an instrument for unveiling the different, "real" and "false" selves (see R. D. Laing), which are hidden in her "alibis" represented by narrators and central characters like Elisa, Andrea, Arturo, Pazzariello, Ida, or Emanuele. Other alibis are embodied in central characters who play the role of fathers and mothers of protagonists such as Teodoro, Wilhelm Gerace, Giuditta, or Aracoeli, who are also tormented by unrequited love and personal disappointments.

Narcissism ${ }^{8}$ is a dominant motif in all of Morante's work. Among her early critics no one is more emphatic than Carlo Sgorlon in suggesting an actual flirtation by the author with her own autobiographical elements. I would definitely extend Sgorlon's observations, which are based on Menzogna e sortilegio and L'isola di Arturo, to her other writings; but I am not sure that, as the critic also suggests, this is a form of "civetteria narcisistica" (cfr. Sgorlon 1972). There is too much suffering in the narcissism of her "alibis" for us to see it in terms of an enticing manifestation of "coquetry." Her "alibis" are all projections of an autobiographical narrator who, tormented, seeks relief (catharsis?) and hope (like a Sheherazade) through her storytelling. Perhaps Cesare Garboli's diagnosis of Arturo's malady as "nevrosi narcisistica" is one of the best diagnoses of Morante's narrator-protagonists. Hardly by chance, as we see in Aracoeli, Emanuele confesses that he is afflicted by "neuroses" and that as a child he was "Narcissus-like."10 In essence, all of Morante's major narrators crave affection, are obsessively concerned with feeling unattractive, and often manifest a very low self-esteem. Moreover, they are all attracted by so-called "beautiful" individuals who seem to be both blessed and cursed by their "beauty." The first, and in many ways the prototype, of all these characters who are afflicted by this curse is unquestionably Edoardo, in Menzogna e sortilegio.

\section{Fiction and Alibis}

Elsa Morante excels in fabulating narrative lies which, like great fables and universal myths, contain basic truths about men and women--truths about their childhood dreams and adulthood disillusionments, about their loves, desires, fears, and anxieties, and about their love-hate, master-slave relationships with "others" and with their own "self." The author's opus shows that her literary imagination capitalizes on mythical, fabulistic, lyrical, and psychological elements, and that it rarely favors political points of view (naturally, with the ex- 
ceptions of Il mondo salvato dai ragazzini and La Storia, where the author treats "history" and political institutions thirsty for power as a "scandal" and/or as a "joke"). To put it succinctly, for the most part, the fiction of our selfdeclared anarchist is highly self-analytical, intensively existential, and deeply rooted in her private life and personal memories.

I must add that just as I use the term "phantasm"ll (and the same goes for several other idioms such as "theater," "performance," "acting," "voices," "narcissisms," and "dreams") I speak of "alibis" primarily because the author herself utilizes these expressions in her novels, in her essays, for the title of her collection of poetry, and in reference to her characters.

The term "alibi," in addition to being the title of a poem (and of the collection of her poetry, Alibi, 1958), is a word that Morante chooses carefully in her well-known reply to " 9 domande sul romanzo." A few critics have made some references to this essay, usually in order to reiterate the author's position on art and on the role of writers in presenting "incorruptible poetic truths." To my knowledge, the term "alibi" has not been defined in relation to her poems and narrative. Speaking about modern writers, in her answer in Nuovi Argomenti, Morante states:

... il romanziere moderno in luogo di invocare le muse, è indotto a suscitare un io recitante (protagonista e interprete) che gli valga da alibi. Quasi per significare, a propria difesa: "s'intende che quella da me rappresentata non è la realtà; ma una realtà relativa all'io di me stesso, o ad un altro io, diverso in apparenza, da me stesso, che in sostanza, però, m'appartiene, e nel quale io adesso, m'impersono per intero." [Morante's italics] ("9 domande" 24-25)

This passage is most revealing, especially for the use of expressions such as "alibi" and "reciting-I" which, while referring to "narrative voices" in novels in general, can easily be applied to practically all of her own writings. Among her "alibis" I include major narrators and protagonists, male and female, who clearly function, in varying degrees, as the author's dramatis personae.

The sixteen poems collected in Alibi were written between 1941 and 1957. In the brief preface, speaking directly to her readers, the author explains that these poems are either an echo or a chorus of her prose (we know that four of them were written specifically for her first two novels) and that, to some extent, they are a form of divertissement because she simply enjoyed the verses for their musicality. However, contrary to what the author may appear to suggest in this preface, her poetry is far too important to be taken lightly. Perhaps Elsa Morante here is fishing for compliments and trying to draw our atention to her so-called hobby of writing poems--a hobby that reveals another important facet of her great creative talent. Nonetheless, a careful reading of Alibi $^{12}$ shows that in her poetry, just as in her short stories and novels, we find some distinct echoes of a familiar voice that repeatedly, with very few variations, unveils the 
personal drama of a highly sensitive person who, from early childhood, senses (exactly as Manuele does in Aracoeli) that she is destined to suffer from rejected love and solitude: "A difficili amori io nacqui" (from"Avventura," Alibi $51)$. And this is a central drama that we see often remembered and re-created with great vividness in every major writing of Morante.

The lyrical voice in Alibi is unmistakably the same voice that we find in Morante's novels where the author-narrator-protagonist sees herself as a Sheherazade (destined to be "fantastica") who must go on narrating in the hope that her stories can bring pleasure to others and some kind of optimism to herself:

\author{
...io sola, unica io \\ so con bellissime fiabe \\ consolare la notte. \\ Non è mio pregio, ma del cielo \\ che mi fece fantastica \\ se degna io sono della grazia.
}

A Voi diletto, a me speranza

rechi l'Oscura. ("Sheherazade," Alibi 29)

The collection Alibi may be brief but it is extremely rich with well-known Morantean leitmotifs. In these poems the author speaks about love, dreams, music, cats, fables, allegory, friends, heroes, Hamlet and other literary characters, and, of course, about herself. In the poem that lends its name to the collection ("Alibi" was composed in 1955, while she was writing Arturo's Island), we find Morante addressing her "alibis" who, as though in a game, hide their true identity under a mask (a "bautta"):

\author{
Qual è il tuo nome? Simile al firmamento \\ esso muta con l'ora. Sei tu Giulietta? o sei Teodora? \\ ti chiami Artú? o Niso ti chiami? Il nome \\ a te serve solo per giocare, come una bautta. \\ Vorrei chiamarti: Fedele; ma non ti somiglia. ("Alibi,"Alibi 57)
}

\title{
Autobiographical Phantasms
}

This brief presentation of Morante's narrative voice(s) is part of a larger study in progress in which I construct a recurring image of what I refer to as a phantasm of the real author that reappears in most of her works. For Wayne Booth in The Rhetoric of Fiction (1961) and for Umberto Eco in The Role of the Reader (1979), this phantasm corresponds to the image of an "implied author" or a "model author" that we construct, consciously or unconsciously, while reading a text. Although I rely on Booth's and Eco's well known views on the role of an 
implied author, the main critical model that lies in the background of my research follows Octave Mannoni's approach illustrated in Clefs pour l'imaginaire ou l'autre scène (1969) and, above all, Charles Mauron's psychocritique elaborated in Des métaphores obsédantes au mythe personnel (1964) whereby a work is examined through recurring "obsessive metaphors." In addition to repeated metaphors I also analyze several familiar Morantean themes (mostly related to love), various images of self-descriptions (many of them clearly narcissistic), and some key characters (lovers, fathers and mothers), who play an important role in the "personal myth" that the author constructs from her early teens, in her short stories, poems and novels.

My project began in the early eighties when I started to examine the role of voices of the model author in Morante's works. As I was working on Eco's Lector in fabula, I was determined to analyze the presence of the "auctor in fabula" which could be reconstructed through an examination of story, discourse and plot as strategies of a real author who carefully narrates, if not a direct autobiography, at least some of the most important events from her life which conditioned her outlook on men, lovers, parents, and literature.

I did not begin my research by consulting biographies in order to construct an initial image of the implied author and then proceed to explain the characteristics of the ever present Morantean phantasm that speaks through parenthetical statements. But, as I read Jean Bellemin Noel's objections to Mauron's "psychocriticism," I realize that I also re-construct from my author's works a "phantasm" of the implied and empirical author, and then "with the help of this figure, to which is added the weight of both intrinsic and extrinsic material (letters, diaries, etc.)," I return "to the text to further its meaning." In other words, after I analyze various voices of different narrators, I define a phantasm which I find to be similar, to some degree, to the empirical author that we may know from extrinsic sources such as interviews and biographies. Following this vicious circle, I return to Morante's texts and, with the help of her (hyper)phantasm, I proceed to explain in greater details certain elements of her work, especially those related to themes of love, rejection, solitude, and despair.

I am well aware that after nearly three decades of discussions on "open works" and on reader reception theories, after Roland Barthes's pronouncement of "the death of the author," and after Derrida and American deconstructionism-- which have focused on the role of the reader and on the autonomy of the self-sufficient text--one may ask how can I speak about implied authors, about author's intentionalities, and, even worse, about empirical authors? I suppose that I could start by seeking the support of well known experts of narratology--from the most established traditional critics on the novel, beginning with Henry James' "House of Fiction " and other essays collected in The Art of the Novel (1934), and Percy Lubbock's The Craft of Fiction (1921), up to Wayne Booth's The Rhetoric of Fiction (1961). I could also resort to 
more recent theoretical works on narrative discourse by French critics like Maurice Blanchot and Gérard Genette. The bibliography on the art of narration and on authorial interventions is much too long to be treated here, but for my discussion I prefer to recall primarily Seymor Chatman's insightful comments on narrators and implied authors in Story and Discourse (1978, see especially chapter 4 and chapter 5) and in Coming to Terms (1990, especially the chapter "In Defense of the Implied Author").

In essence, I fully agree with Chatman that: "Upon publication, the implied author supersedes the real author" (Coming 81), and that "Intention ceases being a private authorial matter: it becomes the work's intent" (Coming 82). But 1 also feel that our readings and interpretations of certain texts (especially those saturated with self-referential, psychological, and literary allusion) are more satisfactory when we can contextualize them and, to a lesser degree, when we feel that we have some knowledge of the author's background. Of course, this knowledge is not a requirement in reading a text, but it is certainly helpful in making conjectures about the narrator, characters, events, and ultimately about the overall possible meaning(s) of the text. Perhaps it is only a question of curiosity, but it seems that whenever we have very little knowledge of the author in our reading process we end up making even more conjectures about the model or implied author. This is precisely the case when we read the novels of Morante.

Elsa Morante was well known for refusing interviews and for her reluctance to discuss her writings and private life (see Venturi). ${ }^{13}$ In a rare interview with Jean Noel Schifano, shortly before her death, she best summarizes her reasons asserting: "Sono tutta intera nei miei libri... Arturo sono io" (Schifano, "Parla"). ${ }^{14}$ This strong statement, "all of me can be found in my works," which, intertextually speaking, echoes similar affirmations such as Flaubert's "M.me Bovary c'est moi," is actually another most convincing suggestion for examining the different allusions to Morante's private life, hidden (masked?) in her work. My study of the author's narrative voices is in fact a compilation of the implied authors that she has clearly underlined from her earliest short stories (many collected in Il gioco segreto (1941) and Lo scialle Andaluso (1963) to her last novel Aracoeli (1982). Again, I am speaking of the constant presence of a never present phantasm who oversees Morante's narrations, and who, as I have stated elsewhere, keeps a close eye especially on those narrators and characters who like "alibis" protect the enigma of her real self. In exploiting this phantasm it is almost as if Morante does not trust completely her narrators to tell her personal stories accurately. Consequently, she chooses to rely on a second voice which guides them and guarantees that their accounts are more faithful to what her phantasm maintains to be the real events of the story.

At this point it is helpful to recall another of Morante's statements on the novel: "il romanzo è ... la proiezione di una psicologia nel mondo; [...] è lecito inventare qualsiasi cosa in un romanzo fuorché la psicologia." ${ }^{15}$ We can take this 
to be the author's basic belief that all narratives, as fantastic as they may appear to be, are realistic in so far as they portray (project) some hidden truths. Therefore, through her narrative voices we can examine an intimate (psychological) image which is portrayed, or, if we wish, psychically projected, over and over again, on the screen of her écriture. I am speaking of those familiar Morantean portraits of narrators, male or female, who desperately crave affection and love, always--and not just during the formative years of childhood and adolescence. The theme of love, and especially unreturned love, is the subject of a much larger topic of discussion, that critics like Sgorlon, Pupino, Siciliano, and Ravanello began to examine in the sixties and seventies, in their pioneering monographic studies of our author.

In my estimation, Elsa Morante's use of a phantasm illustrates quite well Wayne Booth's suggestion that "the emotions and judgements of the implied author are... the very stuff out of which great fiction is made" (The Rhetoric of Fiction 86). Among the many other interesting observations on the "rhetoric of fiction," Booth, speaking of different forms of authorial intervention, mentions how Homer was not able to resist the temptation of clarifying motives, sentiments, actions and events of his heroes through some forms of intrusion. Booth also reminds us that Homer's type of intrusions cannot be used to reveal to us the private life of the author. But, unlike Homer's authorial interventions Morante's interjections (that, except for La Storia, are not in propria persona) can, and do, lead us to some implicit autobiographical allusions to several aspects of her private self and personal life.

For a number of years I have been exploring how Morante's main narrators and some key characters like Teodoro, Wilhelm Gerace, Giuditta, Pazzariello, and Aracoeli, are in essence fictional and metaphorical "alibis" of the same implied author. ${ }^{16}$ My studies of the author's narrative strategies have led me to investigate her unusual talent for exploiting the narcissistic voice of an ever present phantasm that speaks in a variety of parenthetical statements. This has also led me to ask a number of questions, such as: how do these eye-catching interjections relate to the narrator and to the implied author in a specific narration? Are they the same in other works? Do they form a continuum throughout her opera omnia? Are they mostly a manifestation of the author's need to comment on everyone and everything, including her narrator's style of storytelling? These and other related questions intrigued me as I focused on Morante's art in fusing first and third person narrations by male and female narrators who from Elisa to Manuele share many similar characteristics and, most of all, see themselves as victims of the same fate.

A rapid leafing through of Morante's first work, Le straordinarie avventure di Caterina, written during her early teens, would show that it contains no parenthetical statements and no interjections like "in realtà" and "in verità." The reason is quite simple: this is clearly a fable, and, just as in several of her earliest short stories that follow, whenever there are no alibis or phantasms involved, 
the author is not concerned with having to fuse personal truths and fiction. However, beginning with her first novel, Menzogna e sortilegio--widely recognized as a masterpiece of Italian contemporary fiction--something new becomes evident. In the story recreated by Elisa's first person account, as well as in the third person narration developed by the omniscient narrator, we notice the presence of an additional voice that parenthetically explains, interjects, comments, adds, contradicts, supports, or documents some information that the narrator and protagonists do not provide on their own. In short, in different forms of parenthetical statements we notice that the story develops with the help of an official, visible narrator (who has a name, a gender and a personal history) and of an extra-diegetic, invisible narrator (impersonal) who is forever guiding narrators, characters and readers. This extra-diegetic voice that critics like Booth, Eco and Chatman have extensively discussed in terms of an implied author, while it may not have an explicit identity, in essence seems to have several characteristics that Morantean readers would associate quite closely with those of the empirical author.

One of the first and best self-revealing writings of the author is the poem which functions as a preface in Menzogna e sortilegio. The verses "Dedica per Anna, ovvero, alla favola," dedicated to the character Anna, precede the three brief opening chapters with which Elisa introduces herself.

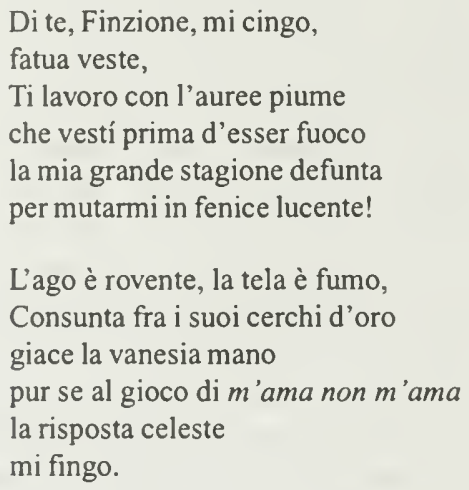

As we can see, there are several key terms related to the art of narrating (to the "Finzione") by an author who returns, like the eternal phoenix (the "fenice"), in every new text. This is also an admission of how she will be using symbols, images, fables, myths, and metaphors that will be exploited in a metafictional fashion and as instruments for revealing part of herself. This poem can actually serve (and the author may have very well planned it to be so) as a preface to all of Morante's opus as it also suggests how she will use "narrative lies" to reveal herself as "Other", while she re-appears like a phoenix in each novel: new, different and yet the same. Moreover in images like "l'ago è rovente, la tela è 
fumo" we recognize some references to the ambiguities that are (intentionally?) hidden in the narrative web woven by an author who works feverishly with her pen (l'ago) on her stories (la tela) used to partly unveil some personal truths and partly to preserve an enigma around her and her private past.

Elisa is the first major narrator ${ }^{17}$ (and alibi) of Elsa Morante. Even in the name of the protagonist-narrator we recognize the obvious association ElisaElsa. And, just as important, Elisa's peculiar style of narration offers the first indications that parenthetical statements serve different functions and that one of these is to emphasize the psychological perspective of an implied author who chooses to speak about herself (as "I") through some intriguing alibis (allegedly as an "Other").

In the opening three short chapters that serve as an introduction, Elisa, as she talks about her family and relatives, offers us many self-revealing characteristics which become extremely valuable for a better understanding of the narrator, of the implied author, and even of the title Menzogna e sortilegio.

Talora, mentre m'aggiro per le stanze, in ozio, il mio riflesso mi si fa incontro a tradimento; io sussulto, al vedere una forma muoversi in queste funebri acque solitarie, e poi, quando mi riconosco, resto immobile a fissar me stessa, come se mirassi una medusa. Guardo la gracile, nervosa persona infagottata nel solito abito rossigno (non mi curo di portare il lutto), le nere trecce torreggianti sul suo capo in una foggia antiquata e negligente, il suo volto patito, dalla pelle alquanto scura, e gli occhi grandi e accesi, che paion sempre aspettare incanti e apparizioni. E mi domando: "Chi è questa donna? Chi è questa Elisa?" Non di rado, come solevo già da bambina, torco la vista dal vetro, nella speranza di vedervi rispecchiata, appena lo riguardi, una tutt'altra me stessa; ché, scomparsa la mia seconda madre, la sola cui piacque di lodarmi, e perfino di giudicarmi bella, rinasce in $\mathrm{me}$, e si rafforza ogni giorno, l'antica avversione per la mia propria figura. (12)

Towards the end of this introduction Elisa adds:

Ebbene: io non cerco il perdono e non spero nell'altrui simpatia. Ciò ch'io voglio, è soltanto la mia propria sincerità. (14)

[...]

Tale gelosia rafforzò la mia inclinazione alla solitudine; e in questa io trovai cosí valida medicina e ristoro che da ultimo ero giunta, pur amando la mia protettrice, a rifuggire spesso da lei. Preferendo la sua presenza immaginaria (trasfigurata e domata dalla mia immaginazione secondo i miei desideri), alla sua presenza carnale. (15)

Expressions like "il mio riflesso," "mi riconosco," "a fissar me stessa," "come se mirassi una medusa," "nella speranza di vedervi rispecchiata," "una tutt'altra me stessa," "rinasce in me," "avversione per la mia propria figura," or "la mia piena sincerità," give us a good clue as to the type of psychological discourse that the narrator is exploiting. These are also excellent hints that we are reading a self-referential and self-revealing story of a narrator who in the process of telling a fictional story feels a need for externalizing some of her deepest thoughts 
and emotional feelings.

We know that Elsa Morante was an avid reader of poetry and literary works of both classic and contemporary authors (from the epical writing of Homer, to the more philosophical and existential writings of Simone Weil, and to the more socially engagé works of P.P. Pasolini), what is hard to prove is the extent to which in Menzogna e sortilegio she is repaying a debt to the great masters of self-conscious narrations and authorial intrusion, such as Cervantes, Fielding, Sterne, or Manzoni. Nonetheless, beginning with L'isola di Arturo her authorial interventions transcend intertextuality and become integral intratextual elements of her own fiction. Most of her parenthetical statements, regardless of their length, interrupt, even if only briefly, the flow of the narration during which the reader can notice a change of tone (or voice) in the story. After a number of similar instances readers become aware that the space between the parentheses is the private space of an extra-diegetic narrator--of an implied author who is speaking to the reader.

In Menzogna e sortilegio this space is occupied by the voice(s) of Elisa and of an implied author who, just as the narrator does, repeats from the beginning of the novel, almost obsessively, expressions like "in realtà" and "in verità,"18 wanting to unveil some truths in a story saturated with "menzogne", "memorie," "sogni," and "racconti." Elisa feels compelled to tell her own version of a family secret that has affected her close relatives for the last three generations. And although she is well aware of having to fabricate her own narrative lies--just as her family members have done for years--her main concern remains to unmask a few hidden truths about herself, her parents (Anna and Francesco), her protector (Rosaria), and the people she loved or hated the most (like Concetta, Teodoro and Edoardo). This concern is further underlined in her need to speak directly to her readers (to the lettori, or voi, or $t u$ ) wanting to convince them that her own story is true:

Tale è la fonte della storia che mi accingo a narrarvi... ma per quanto bizzarra possa apparirvi qua e là, è veritiera dal principio alla fine. (29)

From the opening page of the novel, Elisa reveals quite a bit about herself, about what she has become, and about the futility of trying to escape a condition that she must face:

Fu così che, sulle soglie appena dell' adolescenza, per troppo amore io diventai misantropa." [...]

Ma chi fugge per amore non può trovar quiete nella solitudine. (20)

As Morante's readers discover, Elisa's admission of her solitude, her misanthropy and above all her essential need for love and affection are applicable to all of the author's narrators. 
Menzogna e sortilegio is in essence Morante's macrotext and in Elisa we can discover most of, if not all, the autobiographical elements of the phantasm that we can construct from the author's subsequent narrative voices. Many of these possible autobiographical allusions can be confirmed partly by the few interviews available and mostly from the bits of personal information that we can gather from her notes, letters, diaries (see Diario 1938), essays, and comments from her friends like Moravia, Pasolini, Garboli, Sica, or Fofi. And naturally we cannot ignore the somewhat disturbing biographical portrayal of our author by her brother Marcello Morante in Maledetta benedetta.

In Menzogna e sortilegio parenthetical comments appear even in the epigraphs and subtitles of each chapter; as, for example, with the title of the second chapter: "Santi, Sultani e Gran Capitani in camera mia (S'annuncia il misterioso Alvaro)." This "paratextual" element, as Gérard Genette would define it in Seuils (1987) is just one of the many indications of the presence of an implied author who openly accentuates the metatextual features of the narration. Morante exploits a gamut of paratextual elements in all of her novels. These become much more obvious in her second fiction, L'isola di Arturo, where titles, epigraphs, subtitles, and the whole structure of the novel underlines the intertextual features that the implied author considers as functional elements of the narration.

L'isola di Arturo starts with a poem dedicated to "Remo N." Under the page title we find as epigraph a verse from Umberto Saba. On the next page, under the title of the first chapter, we find another epigraph, this one is a verse by the author's friend and poet Sandro Penna. It is not difficult to guess that the meaning of these verses, dealing with love, memories, and with having lost a personal eden, is directly related to the central meaning of the novel. These verses and various other paratextual elements, together with several literary images (like gardens, talismans, legends, heroes, etc.) prove to be excellent intertextual reminders of how L'isola di Arturo is a Bildungsroman, structured like an epic of adolescence--that is, like a symbolic reconstruction (of universal and mythical dimensions) of a most difficult age when poetry becomes prose and when childhood fantasies turn into bitter realities. Arturo's memories, as well as his illusions and disillusions, are all guided by an implied author who already knows, through hindsight, what Arturo's profound suffering is all about. It is the voice of a Morantean phantasm who knows very well what Wilhelm Gerace and Nunziatella represent in the eyes of young Arturo--the young hero who is literally starved for motherly and fatherly love, and jealously tormented by sibling rivalry.

Evidentemente, essa non aveva ancora fermato il suo pensiero su questa prova inevitabile che l'aspettava. La vidi infatti mutar viso e spaurirsi come se soltanto le mie parole gliela richiamassero alla memoria. (Questo era uno dei tanti segni dell'infanzia che tuttora perdurava in lei: che la sua immaginazione, sempre abbastanza pronta per le favole $\mathrm{e}$ 
simili cose puerili, si mostrava, talora, piuttosto tarda invece per tutto quanto poteva annunciarle pena o avversità. Si sarebbe detto ch'ella si fidava ingenuamente dei giorni, e che attribuiva ad essi una specie di benevolenza coscienziosa: come se anche il tempo avesse un cuore cristiano). (151)

(A distanza di tanto tempo, adesso io vado tentando di capire i sentimenti che, in quei giomi, cominciavano ad accavallarsi stranamente nel mio cuore; ma tuttora mi trovo incapace di distinguere le loro forme, che si mischiavano in disordine dentro di me, e non erano illuminate da nessun pensiero. Al ricordo, mi sembra di scorgere una valle, isolata e profonda, in una notte coperta di dense nuvole: laggiú, nella valle, una turba di creature selvatiche, lupetti, o leoni, ha incominciato, quasi per giocare, una mischia, che diventa grave e sanguinosa. E intanto, la luna cammina al di là delle nuvole, in una zona limpida, assai distante). (138)

In many ways this is a voice similar to the one that in Aracoeli will guide Manuele on his trip to Spain in search of his dead mother Aracoeli.

Gérard Genette's interesting discussions on "paratext," in Seuils, can help us to shed additional light on Morante's type of authorial interventions in different features of her texts, especially Il mondo salvato dai ragazzini and La Storia (where history and autobiography are carefully interwoven). ${ }^{19}$ The titles, the type of divisions in chapters (or the lack of such division), and the overall graphical appearance of these texts (use of different fonts, italics, capitals, etc.), all point to the author's techniques of forcing the reader's attention on specific elements of the text. La Storia--a fiction masterfully structured as an interplay (a fusion and confusion) of story (fiction) and history--became one of the most discussed and controversial Italian narratives of the early seventies. ${ }^{20}$ Most of the controversies provoked by this novel dealt with socio-political issues (raised mainly by Marxist critics), and with the fact that it did not fit either within a neorealistic frame or a neo-experimental trend. Nonetheless very few came close to mentioning the author's exploitation of the "reliability" and "unreliability" of the omniscient narrator. This is a feature of the novel that in itself provides enough material for a separate full length study.

For our discussion it suffices to recall that in the parenthetical statements we notice a voice that cannot be the same voice which recounts the stories of such memorable characters as Ida, Useppe, Ninuzzo, Davide Segre, talking animals (dogs, birds and cats), and of many secondary characters. From the beginning of the novel we notice that a strong authorial voice speaks in parentheses, committed to demonstrate how History, "La Storia" (as written on the cover of the book), is an eternal scandal: "uno scandalo che continua da diecimila anni." In the several documented historical passages (all in italics), which precede each section of the novel, we find more parenthetical statements of a voice that also feels the need to intervene even in the narrator's account of historical events. In short, in La Storia ${ }^{21}$ the author becomes both interpreter and commentator of the story of her characters and of the social injustices that have been afflicting mankind for centuries. 
Il mondo salvato dai ragazzini is a most unique and original contemporary Italian fiction that combines prose, poetry and drama. It is also a text that to date only a handful of critics have analysed and usually in a rather superficial way--seeing it mainly as preliminary to La Storia. Yet, Il mondo contains some of the best socio-political and ideological views adhered to and articulated by the author from the fifties to the late sixties. ${ }^{22}$ At the same time it is a work that may indeed give us the best clue as to how Morante may have also conceived the use of parenthetical statements in the same fashion that the chorus is employed in Greek theater. ${ }^{23}$ Authorial intrusions and the chorus are both seen as a way of exploiting background voices that periodically intervene to underline specific elements of a story.

Because here I do not examine an actual evolution in the author's application of parenthetical statements, from the short stories of $I l$ gioco segreto to her last work, I shall limit my observations on Aracoeli to saying that in her final narration the author becomes much more explicit in emphasizing the presence of her phantasm and thus she utilizes her authorial intrusions more frequently than in any other work (see the statistics below). Let's examine at least one example which illustrates the author's particular use of the term phantasm and two other examples of authorial intrusions:

[...]Amore è uno scambio: vuole dare e ricevere. E se adesso, a 43 anni, io mi sono messo in istrada alla caccia di un fantasma, è perché da tempo ho imparato (e ormai senza più dubbi) che non ho nulla da offrire in degno cambio a nessuno. Non trovo grazia nei cuori. E perfino l'amore pagato (che poi mi attrista al pensiero fino al pianto) ormai sarebbe una merce superiore ai miei mezzi. (51)

(Non sarebbe certo la prima volta che io mi sento imputare dei piú sanguinosi misfatti mondiali: dai campi di sterminio alle guerre imperialistiche, ai genocidii, alle torture poliziesche, all'assassinio del Che Guevara, ai golpe sudamericani, alle manovre della CIA. In piú d'una occasione, a certe mie discolpe confuse, ho visto comparire in risposta, su care facce adolescenti, la già nota smorfia di rigetto che denunciava il mio marchio: Razza borghese! Inutile camuffarsi da convertito. Nessun battesimo potrebbe redimere questo peccato originale della mia carne: cucito forse anche questo addosso a me dal camiciaio immortale?). (60-61)

(In questo, forse, un poco io le somiglio; ma tale eredità di Aracoeli si è degrađata, nello scendere a me, riducendosi a una copia contraffatta e guasta, come la mia favola di Totetaco. Io sono una figurina piatta, che si agita all'impazzata verso la seconda dimensione, e la terza, e la quarta; e si protende assurdamente verso l'ultima, l'Esotica, l'Abnorme). (178)

\section{As a Conclusion}

At this point it may be helpful to glance at a brief summary of the number of parenthetical statements that appear in each of Morante's novels and to see 
them in relation to the number of pages of each work. Once again I underline that here I am speaking exclusively of actual parentheses:

Menzogna e sortilegio (pagine 706): 359 parentheses

L'isola di Arturo (pagine 379): 260 parentheses

Il mondo salvato dai ragazzini (pagine 225): 200 parentheses

La Storia (pagine 657): 638 parentheses

Aracoeli (pagine 328): 614 parentheses.

These figures alone (showing an obvious arithmatic increase in the ratio between parentheses and pages) would suggest that Morante's application of parenthetical statements is a far-reaching integral element of her narrative techniques. We know that after Menzogna e sortilegio Morante with every new fiction presents us with narrators, characters, events, and general ambience that somehow recall those from her previous narratives. By the same token, in each story (re)emerges the presence of a familiar phantasm with similar motives for intervening in the story being told. A careful examination of the voice(s) of this phantasm is most useful in analysing several unifying elements and themes that link Morante's recurring and most important motifs such as childhood, adolescence, solitude, narcissism, unrequited love, feeling unattractive, and a deep despair that speaks about death.

My contention remains that as she rewrites basically the same story of male and female individuals who are obsessed with love, Elsa Morante combines and interjects within her narrator's voice a second voice that echoes incessantly the personal misfortunes of men and women who share the same unhappy experiences in love. A close scrutiny of this second voice--of this Morantean phantasm--demonstrates even better that it is hardly by chance that the author's favorite topics all deal with difficult love relationships between parents and children, husbands and wives, and, naturally, between lovers. Moreover, it is in this phantasm that we recognize an implied author who feels a constant urge to clarify some uncertainties pertaining not only to central characters (like mothers, fathers and lovers), but also, and above all, to those characters who function as the author's alibis and naturally as her dramatis personae.

Elsa Morante is finally receiving in Italy (and also in France) the critical attention that she deserves as one of Italy's most important narrators. With each new study on the author's narrative strategies we can appreciate more and more how Morante was unquestionably a most accomplished fabulator who knew extremely well the art of storytelling. Furthermore, her fascinating fiction demonstrates that she was particularly talented in employing a narrative discourse 
that contains more than one level of "story and discourse" (to recall Chatman) used for examining her characters, her narrators, and above all herself, her persona, and her alibis.

\section{University of Toronto}

\section{NOTES}

* Two different shorter drafts of this article were read at the 1995 meetings of the American Association of Italian Studies (in Saint Louis, Missouri), and the Canadian Society of Italian Studies (at Brock University, St. Catharine, Ontario). The computer assisted research for this paper and part of my work in progress on Elsa Morante's narrative techniques has been made possible by a grant from the Canadian Government. I am most grateful for the SSHRC grant which has allowed me to put in electronic form most of Morante's work. Special recognition must go to my assistant Violeta Kazakova who has been extremely helpful during the second phase of my computer assisted project. Her careful and patient work with the electronic text and her excellent suggestions in selecting parenthetical statements have made my work much easier.

1 In Arturo's Island we find the longest parenthetical statements which at times reach a full page. Here is a most revealing sample from the conclusion: "In seguito, ripensandoci a distanza, mi son domandato se, in fondo, quel suo discorso non fosse poi giusto, almeno in parte... Forse, davvero io, mentre mi credevo innamorato di questa o quella persona, o di due o anche tre persone insieme, in realtà non ne amavo nessuna. 11 fatto è che, in generale, io ero troppo innamorato dell'innamoramento: questa è sempre stata la vera passione mia! Può darsi, in coscienza, ch'io non abbia mai amato sul serio W. G. E in quanto a N., chi era, poi, questa famosissima donna? una povera napoletanella senza niente di speciale, come a Napoli ce ne sono tante! Sì, ho il fondato sospetto che quel discorso non fosse del tutto sbagliato. Il sospetto, non proprio la certezza... Cosí dunque la vita è rimasta un mistero. E io stesso, per me, sono ancora il primo mistero! Da questa infinita distanza, adesso, ripenso a W. G. Me lo immagino, forse, piú che mai invecchiato, imbruttito dalle rughe, coi capelli grigi. Che va e toma, solo, scombinato, adorando chi gli dice parodia. Non amato da nessuno - giacché perfino N., che pure non era bella, amava un altro... E vorrei fargli sapere: non importa, anche se sei vecchio. Per me, tu resterai sempre il piú bello. ... Di lei, a suo tempo, ebbi qualche notizia, a Napoli, attraverso viaggiatori venuti da Procida. Stava bene, di salute, per quanto dimagrata molto. E seguitava la solita sua vita nella Casa dei guaglioni, con Carmine che si faceva ogni giomo piú simpatico. Essa, però, non usava piú chiamarlo Carmine, lo chiamava a preferenza col suo secondo nome di Arturo. E per me, io sono contento che sull'isola vi sia un altro Arturo Gerace, biondino, che a quest'ora, forse, corre libero e beato per le spiagge..." (376-77).

2 Among the first stylistic and linguistic analyses of Morante's work we find those of Pupino (Struttura and "Elsa Morante," and Montefoschi. Even in the interesting brief note of Zago, where the discussion centers on the dimension of écriture, there is again no mention of authorial intrusion as one of Morante's narrative techniques. More recently has appeared an interesting article in which the author mentions parentheses in Arturo's Island; Maria Ferrecchia, " $L$ 'isola di Arturo e Aracoeli di E. Morante. Due stili, un linguaggio," Critica letteraria $91-92$ (1996): $587-610$.

3 See the latest proceedings and collection of essays: Per Elisa. Studi su Menzogna e sortilegio (Pisa: Nistri-Lischi, 1990); Per Elsa Morante (Milano: Linea d'ombra, 1993); and D'Angeli and Magrini. Of interest are also Letture di Elsa Morante (Milano: Rosenberg \& Sellier, 1987), and Schifano and Notarbartolo.

4 I have been using Folio View's and Wordcruncher for Window's for the textual analysis of the 
electronic texts. Both programs are extremely useful for building concordances but also, and even more important for this type of research, for the collection of data of word frequencies and of their synonyms, as well as of collocations of specific words and expressions within a sentence or paragraph.

5 Although the term has psychoanalytical implication, here 1 should point out that the idea of a phantasm came to me from a re-reading of Menzogna e sortilegio, as 1 became aware of how the author, especially in the opening chapters, spoke of phantasms, spirits, voices, shadows, etc. (Garboli has also mentioned these same elements in "Prefazione"). Furthermore, as I began to examine the different voices of the implied author in Morante's opus I realized that just as for Elisa, for other narrators of subsequent novels, their narrations were also interrupted by an authorial voice who speaks through an invisible ever present phantasm whose identity may remain enigmatic, but whose voice soon becomes quite familiar. Here I would like to point out that even though there is no mentioning of the work of Elsa Morante, in Neppi's text I find an enlightening study of writing subjects, autobiography and phantasms that is unquestionably pertinent to my discussion and my use of the term phantasm.

6 See La Stanza separata 63. Also, see Sgorlon's perceptive psychological observations in his monographic study.

7 Morante's gradual seclusion from social life begins to be noticeable soon after her official separation from Alberto Moravia in 1962. As we recall Moravia and Morante met in 1939 and were married in 1942, but soon after their marriage they began to experience the psychological tortures of a love-hate relationship that continued even after their separation. The couple was never divorced.

8 In her diary, 16 august 1952, we read an interesting confession that is related to her self image: "Narcisismo: è questa la ragione per cui mi delizio tanto di esporre il mio corpo al sole? Probabilmente, si, la ragione è questa: giacché, se fossi brutta, non avrei più desiderio di farlo. [...] Per questo ho sempre avuto tanta cura del mio corpo e della sua giovinezza. Un tempo credevo di farlo per l'attesa dell'amore. Adesso ho imparato ormai che, per quanto calé cai agaté, nessuno potrà mai amarmi veramente" (Opere 1, lxi).

9 In his excellent review of L'isola di Arturo Garboli defines the work a beautiful "leggenda eroico-narcisistica." See La stanza separata.

10 "Il bambino Manuele --superdotato e subnormale-- precoce e ritardato-- brutto e narciso" (292). "The child Manuele--super talented and subnormal, precocious and retarded, ugly and Narcissus-like" (Trans. Weaver 276). I should add that the word narcissism appears at least six times throughout the novel.

11 Here are just two examples: "Se talora m'accadde, trovandomi in qualche ricevimento o ritrovo, di partecipare alla conversazione comune e, dimentica di me stessa abbandonarmi un poco agli svaghi, agli interessi dei mondo, ecco uno dei miei gelosi fantasmi apparimi sulla porta" (Menzogna 24). "Io non guardavo né ascoltavo piú nessuno, consumata dall'impazienza di tornare di là, nella mia camera, insieme al mio fantasma capriccioso..." (Menzogna 25). Again I would mention that Neppi's interesting study on "writing subjects, phantasms and autobiography" reinforces my conviction for using the term phantasm for Morante's familiar implied author.

12 This collection which unfortunately has attracted very little critical attention has been republished with an introduction by Garboli.

13 This monographic series of "Il castoro" usually begins with an interview but as we can see from this volume Venturi was not able to get one from the author and thus had to make use of some affirmations coming from her essays (seel).

14 This is in essence what she had also told Venturi.

15 Literally: "the novel is a projection of a psychology of the world... in a novel it is fair to invent anything except psychology" ("9 domande" 17). Other replies (much shorter than Morante's) were given by Bassani, Calvino, Cassola, Moravia, Solmi, and Zolla.

16 My article "Sheherazade" deals specifically with this issue.

17 For a possible precursor of Elisa, and for some definite preliminary projections of Morantean 
phantasms and alibis, one should read the fascinating short novel Qualcuno bussa alla porta, which had appeared, in serial form, in the joumal I diritti della scuola, between 1935 and 1936 . Eugenio Ragni was one of the first critics to discuss this important short fiction (see Capozzi "Sheharazade"). Today it is finally receiving some wider attention; see, for example, Elisabetta Nelsen, "Qualcuno bussa alla porta: Analisi tematica del primo romanzo di Elsa Morante," Forum Italicum 28.2: 269-80.

18 The interjections "in realtà" or "in verità," and at times both, appear as frequently as four times in a page. See for example pages 283 and 562 .

19 In $I l$ mondo. See especially the opening poem "Addio" (dedicated to her friend Billow Morrow) and the exceptional adaptation of the Oedipal play "La serata a Colono."

20 Immediately after the publication of the novel in Italy journalists and critics began numerous debates on whether or not Morante collaborated with her editor in orchestrating a marketing strategy which guaranteed that La Storia would become a best seller. As a possible starting point for reconstructing these polemics I would suggest Ferretti.

21 It should be pointed out that Morante's use of capitals in the title (in Italian one capitalizes only the first word) is in itself an intentional paratextual element that alludes to the fusion of story and history (storia and Storia).

22 See Pro o contro la bomba atomica; also see "Piccolo manifesto dei comunisti (senza classe e senza partito)"--an essay written around 1970 and published in Linea d'ombra (settembre 1980): 3-5.

23 Here I would simply underline that from $I l$ gioco segreto on we find numerous references to stages, actors, characters, chorus, masks, and overall allusions to elements of theatricality.

\section{WORKS CITED}

Bellemin-Noel, Jean. "Textuanalysis and Psychoanalysis." SubStance 59 (1989):102-1 1.

Blanchot, Maurice. The Glaze of Orpheus. Essays ed. Paul Adams Sitney. New York: Station Hill Press, 1981.

Booth, Wayne. The Rhetoric of Fiction. Chicago: U of Chicago P, 1961.

Capozzi, Rocco. "Sheherazade and Other Alibis: E. Morante's Victims of Love." Rivista di studi italiani 5-6 (1987-1988): 51-71.

"E. Morante's Aracoeli: The End of a Journey." Donna. Women in Italian Culture.

Ed. Ada Testaferri. Ottawa: Dovehouse Editions, 1989. 47-58.

"Elsa Morante: The Trauma of Possessive Love and Disillusionment." Contempo-

rary Women Writers in Italy. Ed. Santo L. Arico. Amherst: U of Michigan P, 1990. 11-26.

Chatman, Seymor. Story and Discourse. Ithaca: Cornell UP, 1978.

Coming to Terms. Ithaca: Cornell UP, 1990.

D'Angeli, Concetta, and Giacomo Magrini, eds. "Vent'anni dopo La Storia. Omaggio a Elsa

Morante." Studi novecenteschi 47-48 (1994).

Ferretti, Gian Carlo. Il bestseller all'italiana. Roma-Bari: Laterza, 1983.

Fortini, Franco. Nuovi saggi. 2 voll. Milano: Garzanti, 1987.

Garboli, Cesare. La stanza separata. Milano: Mondadori, 1969. 56-71.

- "Prefazione." Elsa Morante. Menzogna e sortilegio. Milano: Einaudi, 1990.

Genette, Gérard. Figures III. Paris: Éditions du Seuil, 1972.

Seuils. Paris: Éditions du Seuil, 1987.

Laing, R.D. The Divided Self. Harmondsworth: Penguin Books, 1971.

The Self and Other. Harmondsworth: Penguin Books, 1969.

Mannoni, Octave. Clef pour l'imaginaire ou l'autre scéne. Paris: Editions du Seuil, 1969.

Mauron, Charles. Des métaphores obsédants au mythe personnel Paris: José Corti, 1964.

Mengaldo, Pier Vincenzo. “Spunti per un'analisi linguistica dei romanzi di E. Morante.” D’ Angeli and Magrini 11 -36.

Montefoschi, Giorgio. "Funzione dei personaggi e linguaggio in Menzogna e sortilegio." Nuovi Argomenti 15 (1969): 252-67. 
Morante, Elsa. "Qualcuno bussa alla porta." I Diritti della scuola (sett. 1935 - agostol 936). Menzogna e sortilegio. 1948. Torino: Einaudi. 1982.

L'Isola di Arturo. Torino: Einaudi. 1957.

Alibi. Milano: Longanesi, 1958. Also, ed. Cesare Garboli. Torino: Einaudi. 1980. "9 domande sul romanzo." Nuovi argomenti maggio-giugno 1959: 17-38. Now in

Pro o contro la bomba atomica 41-74.

La Storia. Torino: Einaudi, 1974.

Aracoeli. Torino: Einaudi, 1982.

Aracoeli. Trans. William Weaver. NewYork: Random House, 1984.

Pro o contro la bomba atomica. Ed. Cesare Garboli. Milano: Adelphi, 1987.

Opere. 2 voll. Ed. Carlo Cecchi e Cesare Garboli. Milano: Mondadori, 1988-1990.

Diario 1938. Ed. Alba Andreini. Torino: Einaudi 1989. Also in Opere 2.

Morante, Marcello. Maledetta benedetta. Milano: Garzanti, 1986.

Neppi, Enzo. Soggetto e fantasma. Figure dell'autobiografia. Pisa: Pacini Editore, 1991.

Pupino, Angelo. Struttura e stile della narrativa di Elsa Morante. Ravenna: Longo, 1968.

$715-43$

Rosa, Giovanna. Cattedrali di Carta. Milano: Il saggiatore, 1995.

Schifano, Jean Noel, and Tjuna Notarbartolo, eds. Cahiers Elsa Morante. Napoli: Edizioni

Scientifiche Italiane, 1993. . "Parla Elsa Morante. Barbara e divina." L'Espresso (2 Dic. 1984): 122-33.

Sgorlon, Carlo. Invito alla lettura di Elsa Morante. Milano: Mursia, 1972.

Siciliano, Enzo. "Elsa Morante." Autobiografia letteraria. Milano: Garzanti, 1970. 136-68.

Venturi, Gianni. Elsa Morante. Firenze: La Nuova Italia, 1977.

Zago, Esther. "ll carattere di stampa come segno ne Lo scialle andaluso di Elsa Morante." Il lettore di provincia 81 (1991): 33-39. 